\title{
Investigating the Factors Affecting Students' Smartphone Purchasing Behaviors in the Context of Mobile Learning
}

\author{
https://doi.org/10.3991/ijet.v14i22.11748 \\ Hana A.B Elammari $(\bowtie)$ \\ International Higher Institute for Sciences and Technology-Al Garaboulli, \\ AL Garaboulli, Libya \\ mum.modymramegmail.com \\ Nadire Cavus \\ Near East University, Nicosia, Cyprus
}

\begin{abstract}
Since we are living in the information era, it is highly important that people can reach the desired knowledge whenever required. Mobile devices have become indispensable in the everyday lives of humans. The recent developments in the field of technology have affected all sectors as well as the education sector, and have thus increased the importance of mobile learning. However, in order to gain the maximum benefit from mobile learning, it is important to know the specifications of the mobile devices used by the students so that the teaching materials can be prepared accordingly. Therefore, it is necessary to understand the factors that affect students' choices when they are making the decision to purchase a mobile phone. Differences are observed between countries, as there are differences between students. In this context, when the literature is studied, it is seen that insufficient research has been conducted in many countries, particularly in Northern Cyprus. This study focuses on investigating the factors affecting university students' mobile phone purchasing behaviors in North Cyprus. Data was collected from 472 voluntary students by using a survey research model. The factors affecting students' mobile phone purchasing behaviors, such as brand image, price, product/application features, and peer group influence were considered in this study. Consequently, four hypotheses were proposed and only one of these hypotheses was not supported. In other words, brand image, product/application features, and peer group influence were found to be effective factors in students' choice, while the price seemed not to be an important factor. The most important result of the study was that the smartphones occupy a very important place in students' everyday lives and they were not affected by price considerations. Therefore, it is thought that these high demands of students for smartphones will be very advantageous in the transition of educational institutions to mobile learning, particularly from the perspective of teachers. It can be said that students' familiarity with using mobile technologies will affect their motivation positively and this may also positively affect their academic success rates in mobile learning. Therefore, it is hoped that the results obtained in this study will guide teachers in developing countries to prepare their course materials and consequently revise their curriculum in the context of mobile learning.
\end{abstract}


Keywords - Mobile learning; student; smartphone; smartphone purchase intention; mobile devices; developing countries

\section{$1 \quad$ Introduction}

In recent years, the interest in smartphones has increased considerably [1]. It is well known that today, every individual owns at least one mobile phone, while some individuals even purchase more than one smartphone. With respect to the increasing interest in smartphones, manufacturers are developing new models with added features and offering them to consumers. This approach is making it difficult for consumers to decide which model of smartphone to purchase [2]. Some of these models seem to be popular with consumers and can therefore be sold easily. However, some smartphones do not attract the interest of the consumers and face challenges on the market. Resultantly, it is important to investigate and determine the factors affecting the decisions of consumers when purchasing a smartphone. Thus, both the smartphone manufacturers and the researchers have started to conduct studies in this area [3]. Marketing strategies are very important for smartphone manufacturers before they develop new models of smartphone as well as for informing their customers regarding the features of these new smartphones [1]. Smartphone manufacturers have already started to develop new models based on their new marketing strategies [4]. It is therefore concluded that many different factors affect the purchase decisions of the consumers. In particular, the main factors affecting the decisions of the consumers are: Brand concern $[5 ; 6 ; 7]$ price $[8 ; 9 ; 3]$, hardware $[10 ; 11]$, camera $[12 ; 13 ; 14 ; 4]$, purchase intention $[15 ; 16]$, peer group influence [17] and social influence $[18 ; 19 ; 2]$.

In this study, the factors affecting the decisions of student groups, specifically university students in Northern Cyprus, in terms of purchasing a smartphone have been investigated. In the digital age, smartphones allow a diversity of educational environments [20] and have changed the methods of both teaching and learning. This has interested for researchers, especially in the field of education. Consequently, the number of studies in this direction are continually increasing.

\subsection{Mobile devices and mobile learning}

Open Portable mobile devices, which are mobile devices, enable users to connect to the Internet and access its contents [21]. Similar to laptops, these mobile devices enable users to access documents and a range of mobile apps in their pockets [22;23]. If we consider that we are living in the era of knowledge, these mobile devices, with their many features, have also attracted the attention of the education sector since they enable users to access knowledge from anywhere and at any time, without any restrictions [24]. Because of this, the education provided using such mobile devices to reach the knowledge from anywhere and at any time is called mobile learning [25]. Currently, this has resulted in researchers conducting relevant studies in many fields, such as in learning a foreign language [26, 27], in computer science education [28] in science education [29], and in mathematics education [30], etc. However, if one con- 
siders the features of the mobile devices and if one knows the factors affecting the consumers' decisions when purchasing a smartphone, this provides an insight for smartphone manufacturers that will enable them to develop smartphones with the correct specifications and as desired by the consumers. This, this will undoubtedly help more students to use mobile learning technologies. Additionally, this may result in teachers adjusting and configuring their lessons according to the mobile learning principles and thus offering more effective education-teaching.

\section{$2 \quad$ Methodology}

\subsection{Research model}

A survey method was used in the study to collect data from the volunteer university students. The following model (Fig 1) was developed by considering the factors such as the brand image, price, product features, purchase intention, and peer group influence affecting the smartphone purchase intentions.

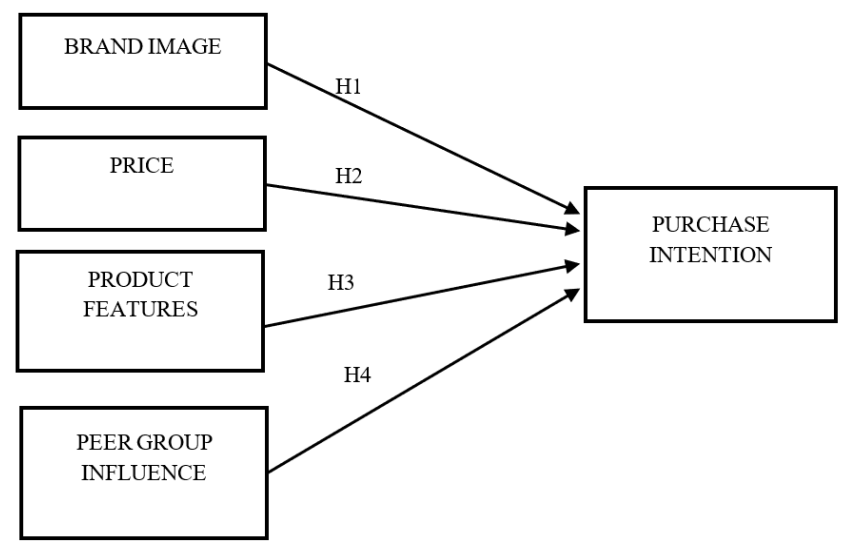

Fig. 1. Adopted model for this study

\section{$2.2 \quad$ Hypotheses}

The following hypotheses were proposed based on the factors of brand image, price, product/application features, purchasing intention, and peer group influence affecting students' intentions to purchase a smartphone by considering the above research model.

- H1: Brand Image has a significant influence on the smartphone Purchase Intention of students.

- H2: Price has a significant influence on students' smartphone Purchase Intention. 
- H3: Product/Application Features have a significant influence on the smartphone Purchase Intention of students.

- H4: Peer Group Influence has a significant influence on the smartphone Purchase Intention of students.

\subsection{Participants}

A total of 472 volunteer students from the three largest universities in North Cyprus, namely Near East University, Eastern Mediterranean University and Cyprus International University, participated in the study. These students were studying ITrelated subjects, such as Management of Information Systems, Computer Engineering, Information Technology and Computer Information Systems. The RAOSOFT program (http://www.raosoft.com/samplesize.html), which is provided free of charge on the Internet, was used in order to determine whether or not the number of students participating in the study was sufficient. It was found that the number of students participating in the study was sufficient. Table 1 shows the participants' demographic information.

\subsection{Data collection tools}

After conducting a literature review, the researchers found that a variety of different factors affect the decision to purchase a mobile phone. In this study, five factors were considered, as shown in Table 2. Ethical approval was obtained from the Ethical Committee for Scientific Research of the university after reviewing the developed questionnaire.

The questionnaire consists of two sections. The first section includes the demographic information of the participants, such as age, nationality, department, university and their level of study. The second section consists of 37 items related to the factors influencing university students' smartphone purchase intentions. A 5-point Likert scale was used to rank the participants' responses (Strongly Agree 5 points and strongly disagree 1 point). The Cronbach's alpha was calculated to assess the reliability of the questionnaire. Robinson, Shaver and Wrightsman [32] underlined that the Cronbach's alpha should be at least 0.6. The reliability test results showed that the Cronbach alpha for the overall questionnaire was .916. This means that the entire questionnaire can be used to collect data for scientific purposes.

A total of 500 paper-based questionnaires were distributed among the three universities by the researchers. However, 19 questionnaires went missing and were therefore eliminated from the study. During the process of entering data into the Statistical Package for the Social Sciences (SPSS), it was found that some of the questionnaires had not been fully completed and as a result, 9 questionnaires were removed from the analysis. In addition, a total of 472 questionnaires were taken and considered in the analysis. The return rate was calculated to be $94.4 \%$. 
Table 1. Demographic information of participants $(\mathrm{N}=472)$

\begin{tabular}{|c|c|c|c|}
\hline Demographic Variable & & Number & Percentage \\
\hline \multirow{3}{*}{ University } & NEU & 172 & 36.4 \\
\hline & $\mathrm{CIU}$ & 144 & 30.5 \\
\hline & EMU & 156 & 33.1 \\
\hline \multirow{2}{*}{ Gender } & Male & 263 & 55.7 \\
\hline & Female & 209 & 44.3 \\
\hline \multirow{3}{*}{ Age group } & $18-22$ & 181 & 38.3 \\
\hline & $23-27$ & 175 & 37.1 \\
\hline & $28+$ & 116 & 24.6 \\
\hline \multirow{2}{*}{ Level } & Undergraduate & 242 & 51.3 \\
\hline & Postgraduate & 230 & 48.7 \\
\hline \multirow{4}{*}{ Department } & $\begin{array}{l}\text { Computer Information } \\
\text { Systems }\end{array}$ & 117 & 24.8 \\
\hline & $\begin{array}{l}\text { Management Information } \\
\text { Systems }\end{array}$ & 16 & 3.4 \\
\hline & Information Technology & 132 & 28.0 \\
\hline & Computer Engineering & 207 & 43.9 \\
\hline \multirow{3}{*}{ Faculty } & Applied Sciences & 248 & 52.5 \\
\hline & Engineering & 175 & 37.1 \\
\hline & Education & 49 & 10.4 \\
\hline \multirow{6}{*}{ Nationality } & Cypriot & 20 & 4.2 \\
\hline & Turkish & 57 & 12.1 \\
\hline & Nigerian & 119 & 25.2 \\
\hline & Libyan & 164 & 34.7 \\
\hline & Iraq & 71 & 15.0 \\
\hline & Other & 41 & 8.7 \\
\hline
\end{tabular}

Table 2. Reliability test of the questionnaire

\begin{tabular}{|l|l|c|c|}
\hline \multicolumn{1}{|c|}{ Dimensions } & \multicolumn{1}{c|}{ Reference } & Number of Items & Cronbach Alpha \\
\hline Brand Image & Tee et al. [15] & 5 & .804 \\
\hline Price & Cheong and Park [31] & 5 & .736 \\
\hline $\begin{array}{l}\text { Product /Applications } \\
\text { Features }\end{array}$ & Jainarain [10] & 13 & .863 \\
\hline Peer Group Influence & Lee [17] & 11 & .658 \\
\hline Purchase Intention & Ling et al. [16] & 3 & .758 \\
\hline Total items & & 37 & .916 \\
\hline
\end{tabular}

\subsection{Data analysis methods}

The collected demographic information of the participants was analyzed by using descriptive statistics. ANOVA was used to determine whether the created model was significant or not. The Multiple Linear Regression Analysis method was applied in estimating the research model results. 


\subsection{Research procedure}

The detailed steps of the study are explained in Figure 2. Here, the research process was implemented in 7 steps. In Step 1, a literature review is carried out, while step 2 involves the development of the questionnaire to be used in the study. Approval is obtained from the university Ethical Committee in Step 3. After this step, data is collected in Step 4 and a reliability test is carried out in Step 5. Finally, in Steps 6 and 7, the collected data is analyzed and comments are made on the results of the study in steps 6 and 7, respectively.

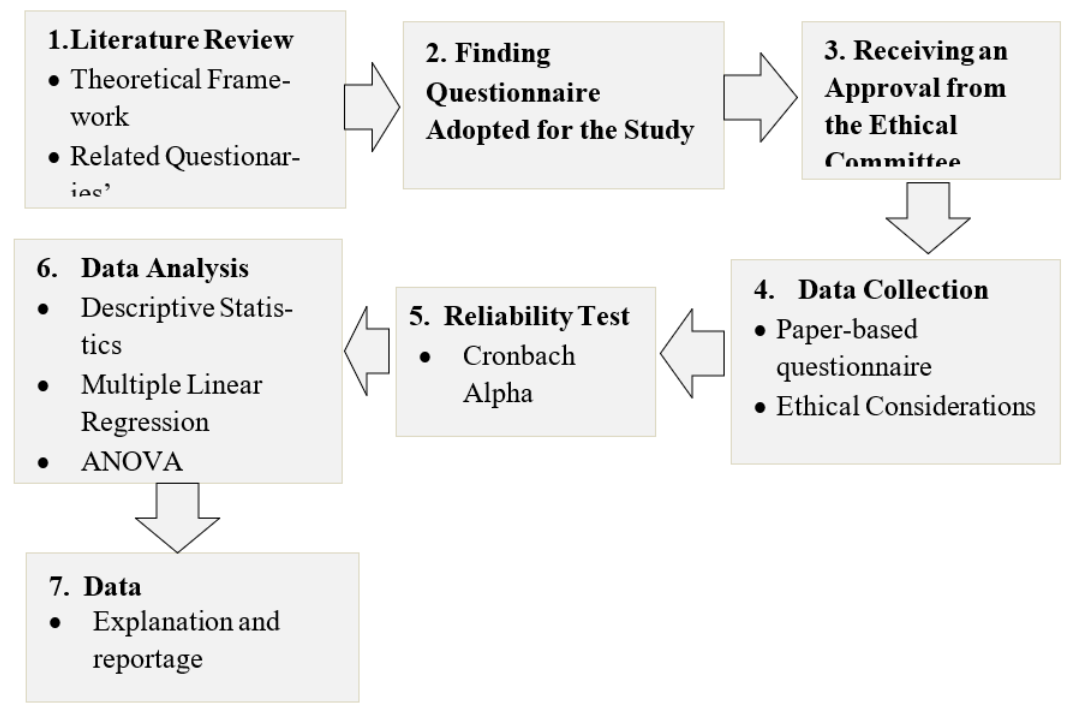

Fig. 2. Research process of the study

\section{Results and Discussion}

\subsection{Correlations among the critical factors}

The correlation matrix, which shows the correlation between the constructs of the research model, is shown in Table 3. Pearson Correlation analysis results identified that five critical constructs were significantly correlated with each other. Therefore, the model was considered to be suitable for regression analysis. 
Table 3. Correlation matrix of five critical factors of the study

\begin{tabular}{|l|c|c|c|c|c|}
\hline \multicolumn{1}{|c|}{ Dimensions } & $\mathbf{1}$ & $\mathbf{2}$ & $\mathbf{3}$ & $\mathbf{4}$ & $\mathbf{5}$ \\
\hline Brand Image & 1 & & & & \\
\hline Price & $.188^{* *}$ & 1 & & & \\
\hline Product/Application Features & $.840^{* *}$ & $.256^{* *}$ & 1 & & \\
\hline Peer Group Influence & $.682^{* *}$ & $.419^{* *}$ & $.663^{* *}$ & 1 & \\
\hline Purchase Intention & $.708^{* *}$ & $.168^{* *}$ & $.755^{* *}$ & $.477^{* *}$ & 1 \\
\hline
\end{tabular}

\subsection{Hypotheses testing}

The multiple regression analysis results of the study are represented in Table 4. The model formed with the ANOVA results was considered to be meaningful ( $p>.05)$. The enter method was used to determine which predictors (brand image, price, product/application features and peer group influence) may impact the dependent variable (purchase intention). In addition, the multiple linear regression analysis results suggest that $59.4 \%\left(\mathrm{R}^{2}=.594, \mathrm{p}<.05\right)$ variance of purchase intention of university students to buy smartphone can be explained by five critical variables, namely brand image, price, product/application features and peer group influence in the study.

Table 4. Influence of five factors on smartphone purchase intention

\begin{tabular}{|l|c|c|c|c|c|c|}
\hline \multicolumn{7}{|c|}{ Dependent variable: Student smartphone purchase intention } \\
\hline & \multicolumn{2}{|c|}{$\begin{array}{c}\text { Unstandardised } \\
\text { coefficients }\end{array}$} & $\begin{array}{c}\text { Standardised } \\
\text { coefficients }\end{array}$ & & & \\
\hline Model & $\mathrm{B}$ & Std. Error & $\beta$ & $\mathrm{t}$ & $\mathrm{p}$ & Decision \\
\hline Constant) & .109 & .144 & & & & \\
\hline Brand Image (H1) & .318 & .062 & .300 & 5.170 & .000 & Supported \\
\hline Price (H2) & .013 & .034 & .012 & .375 & .708 & Unsupported \\
\hline $\begin{array}{l}\text { Product/Application Features } \\
\text { (H3) }\end{array}$ & .772 & .075 & .576 & 10.266 & .000 & Supported \\
\hline Peer Group Influence (H4) & -.177 & .069 & -.115 & -2.565 & .011 & Supported \\
\hline $\begin{array}{l}\text { Model F = 170.922 } \\
\text { R2=.594 }\end{array}$ & & & & & & \\
\hline
\end{tabular}

* Level of .05 shows that difference in mean is significant

Influence of brand image on smartphone purchase intention: Hypothesis $\mathrm{H} 1$ was supported by considering the coefficients in Table $4\left(\mathrm{~F}=170.922 ; \mathrm{R}^{2}=.594\right.$; $\mathrm{p}<.05$ ). According to these results, it was found that the model is statistically significant. Brand Image accounts for $30 \%$ of the variance in university students' smartphone purchase intention $(\beta=.300)$. In addition, the coefficient $(p<0.05)$ indicated that Image Brand had a significant and positive influence on university student's smartphone Purchase intentions. A similar result was found by Chow et al. [33] in the literature.

Influence of price on smartphone purchase intention: As can be seen from Table 4, on the contrary, Hypothesis $\mathrm{H} 2$ is not supported by considering the coefficients 
under the Price $\left(\mathrm{F}=170.922 ; \mathrm{R}^{2}=.594 ; \mathrm{p}>.05\right)$. Also, the overall regression model is not significant $(\mathrm{p}>0.05)$. This means that Price was not a significant factor in predicting the Purchase Intention of university students. It would not be wrong to say that reducing the Price of smartphones might not have a significant influence on smartphone Purchase Intentions. A similar result was obtained by Star [3] and Tee et al. [15]. Price accounted for only $1 \%$ of the variance in university students' smartphone purchase intentions $(\beta=.012)$.

Influence of product/application features on smartphone purchase intention: From Table 4, it can be seen that hypothesis $\mathrm{H} 3$ was supported by considering the coefficients under Product/Application Features $\left(\mathrm{F}=170.922 ; \mathrm{R}^{2}=.594 ; \mathrm{p}<.05\right)$. The Linear Regression analysis results revealed that the overall regression model of the study is significant $(p<0.05)$. Product/Application Features accounts for $57.6 \%$ of the variance in the smartphone Purchase Intention $(\beta=.576)$. Therefore, this significant value implied that Product/Application Features have a significant and positive influence on smartphone Purchase Intentions. It can be claimed that as the features and applications of smartphones increase, the students' intentions to purchase such smartphones will increase proportionally. Similar results were obtained in the literature by Al-Azzawi and Anthony [19].

Influence of peer group influence on smartphone purchase intention: As can be seen in Table 4, Peer Group Influence was determined with the coefficients in Price hypothesis $\mathrm{H} 4\left(\mathrm{~F}=170.922 ; \mathrm{R}^{2}=.594 ; \mathrm{p}<.05\right)$. It can be said that the overall regression model is significant $(\mathrm{p}<0.05)$. $\beta=-.115$ specified the Peer Group Influence reasons for $11.5 \%$ of the variance in smartphone Purchase Intention. The analysis results showed that $\mathrm{H} 4$ is supported, but in the opposite direction. This means that Peer Group Influence had a significant and negative influence on university students' smartphone Purchase Intentions. However, in the research of Lee [17], a contrary result was found.

\section{Conclusion and Recommendations}

This study has focused on investigating the factors affecting university students' smartphone purchasing behaviors in North Cyprus. The factors affecting students' purchasing behaviors, such as brand image, price, product/application features, and peer group influence were considered and a study was carried out. In this study, four hypotheses were proposed and only one of these four hypotheses was not supported. In other words, brand image, product/application features, and peer group influence were found to be effective factors in students' choice, while the price seemed not to be an important factor. The most important result of the study was that the smartphones occupy a very important place in students' lives and regardless of the price of the smartphones, the results were not affected. Therefore, it is thought that these high demands of students for smartphones will be very advantageous in the transition of educational institutions, to mobile learning, particularly for teachers. It can be said that students' familiarity with using mobile technologies will affect their motivation positively and this may also positively affect their academic success rates 
in mobile learning. Therefore, it is hoped that the results obtained in this study will guide teachers in developing countries to prepare their course materials and consequently revise their curriculum in the context of mobile learning.

There are some limitations in this study, as with all other studies. The results could have been more meaningful and more general if the study period was longer and students from all the universities in North Cyprus had participated in the study. Also, in this study, only quantitative research was performed. If qualitative analysis is also carried out using interviews, then deeper and more detailed results can be obtained about the factors affecting university students' behaviors when purchasing smartphones. The results about the factors affecting the purchasing behavior could be useful to researchers, mobile device manufacturers, and educational institutes. It is hoped that this research study will fill the missing gaps in this field.

\section{Acknowledgement}

The authors acknowledge and thank all students who spent their valuable time by participating in this study.

\section{References}

[1] Farheen, S. (2017). Consumer buying behaviour in smartphones. Reflections Journal of Management, 6(1). Retrieved July 16, 2019 from http://reflections.rustomjee.com/index. $\mathrm{php} / \mathrm{reflections/article/view/127/pdf}$

[2] Divya, P.K., Venkata, S., \& Krishna, K. (2016). Comparative analysis of smart phone operating systems Android, Apple IOS and Windows. International Journal of Scientific Engineering and Applied Science, 2(2): 432-438.

[3] Star, V. (2013). Sales forecasts for existing consumer products and services: Do purchase intentions contribute to accuracy? International Journal of Forecasting, 16(3): 383-397. https://doi.org/10.1016/s0169-2070(00)00058-3

[4] Ifeanyichukwu, C., \& Azikiwe, N. (2016). Factors influencing smartphone purchase behavior among young adults in Nigeria. International Journal of Recent Scientific Research, 7(9): 13248-13254.

[5] Healey, M.W. (2008). The influences of advertising endorser, brand image, brand equity, price promotion on purchase intention: the mediating effect of advertising endorser. The Journal of Global Business Management, 5(1): 224-233. https://doi.org/10.5539/ibr. $\underline{\mathrm{v} 5 \mathrm{n} 4 \mathrm{p} 55}$

[6] Husso, N. (2011). Using Android operating platform for Chemical engineering projects: higher education in rural area. New Horizons in IT, 5(2): 95-98.

[7] Azad, S., \& Safaei, H. (2012). Consumer decision-making styles in Malaysia: an exploratory study of gender differences. European Journal of Social Sciences, 10(4): 574-584.

[8] Chew, C. (2012). Perspectives on cross-cultural, ethnographic, brand image, storytelling, unconscious needs, and hospitality guest research. International Journal of Technology, 3(2): 40-52. https://doi.org/10.1108/s1871-3173(2009)0000003013

[9] Kiong, A. B., Reynaldo, M. M., Cid, G. F., Gian, F. R., Gustavo, Q. S. \& Renata, L. (2013). Brand relationships on retailing: the impact of image on behavioural intentions of consumers. Journal of Social Sciences, 4(1): 170-186. 
[10] Jainarain, R. (2012). Attributes that influence Generation-Y consumers in their choice of Smartphone. Master Thesis, Department of Business Administration, Gordon Institute of Business Science, University of Pretoria.

[11] Sujata, J., Yatin, J., Abhijit, C., Noopur, S., \& Ruchi, D. (2016). Factors affecting smartphone purchase among Indian youth: a descriptive analysis. Indian Journal of Science and Technology, 9(15): 4-10. https://doi.org/10.17485/ijst/2016/v9i15/92117

[12] Malviya, S., Saluja, M.S \& Thakur, A.S. (2013). A study on the factors influencing consumers' purchase decision towards smart phones in Indonesia. International Journal of Advance Research in Computer Science and Management Studies, 1(6): 14-21.

[13] Mohan, A. (2014). Consumer behavior towards smartphone industry in Indian market. Master Thesis, MBA Business Management, Dublin Business School. Retrieved July 16, 2019 from http://esource.dbs.ie/bitstream/handle/10788/1812/mba_mohan_a_2014.pdf? sequence $=1$

[14] Nagarkoti, B. (2015). Factors influencing consumer behavior of smartphone users. Retrieved July 16, 2019 from https://www.scribd.com/document/333717977/NagarkotiBishal-pdf

[15] Tee, P.K., Gharleghi, B., Chan, B., Samadi, B., \& Balahmar, A.A. (2015). Purchase Intention of International Branded Clothes Fashion among Younger's in Jakarta. International Journal of Business and Social Research, 5(8): 221-228. 8-17.

[16] Ling, L.P., Lang, P.K., Fong, T.C., \& Perinpajothi, T.S. (2014). Factors affecting purchase intention towards smartphone brand: a study of young female adult consumers. Final Year Project, UTAR. Retrieved July 16, 2019 from: http://eprints.utar.edu.my/1714/3/ Final Year Project.pdf

[17] Lee, S.Y. (2014). Examining the factors that influence early adopters' smartphone adoption: The case of college students. Telematics and Informatics, 31(2): 308-318. https://doi.org/10.1016/j.tele.2013.06.001

[18] Farzana, R. K. (2012). Factors affecting mobile phone purchase in the greater Accra region of Ghana: A Binary Logit model approach. International Journal of Marketing Studies, 7(2): 154-155. https://doi.org/10.5539/ijms.v5n6p151

[19] Al-Azzawi, M., \& Anthony, M. (2012). Students brand preferences between Apple and Samsung Smartphone. Master Thesis, School of Sustainable Development of Society and Technology, Mälardalen University. Retrieved July 16, 2019 from http://www.divaportal.org/smash/get/diva2:538845/fulltext01

[20] Coskun, T.K., \& Gokcearslan, S. (2019). Examination of cyberloafing studies in education: a content analysis. World Journal on Educational Technology: Current Issues, 11(1): 94-103. https://doi.org/10.18844/wjet.v11i1.3990

[21] Bhargavi, P., Prasad, D., \& Dipti, P. (2016). Comparison of mobile operating systems. International Journal of Innovative Research in Computer and Communication Engineering, 4(8): 15281-15286.

[22] Gin, T.S., \& Suan, C.T. (2011). Consumer purchase preferences towards foreign and domestic branded electrical appliances. International Journal of Undergraduate Studies, 1(1). Retrieved July 16, 2019 from http://ijuuitm.blogspot.com/2011/09/vol1-no-1-2012forthcoming.html

[23] Stan, E., Safta, C.G., Suditu, M., \& Iurea, C. (2019). Mobile learning in Romania, a failed experience? New Trends and Issues Proceedings on Humanities and Social Sciences, 6(1): 296-303. https://doi.org/10.18844/prosoc.v6il.4181

[24] The, M.M., \& Usagawa, T. (2018). Investigation of students' mobile phone usage and influences towards their mobile learning adoption: a case study in Myanmar. International 
Journal of Interactive Mobile Technologies, 12(5): 43-57. https://doi.org/10.3991/ijim. v12i5.8924

[25] Uzunboylu, H., Cavus, N., \& Ercag, E. (2009). Using mobile learning to increase environmental awareness. Computers \& Education, 52(2): 381-389. https://doi.org/10.1016/ j.compedu.2008.09.008

[26] Cavus, N. \& Ibrahim, D. (2009). M-learning: an experiment in using SMS to support learning new English language words. British Journal of Educational Technology, 40(1): 78-91. https://doi.org/10.1111/j.1467-8535.2007.00801.x

[27] Nguyen, V.A., \& Pham, V.C. (2011). Learner open modeling in adaptive mobile learning system for supporting student to learn English. International Journal of Interactive Mobile Technologies, 5(4): 22-29. https://doi.org/10.3991/ijim.v5i4.1789

[28] Ramle, R., Rosli, D.I., Nathan, S.S., \& Berahim, M. (2019). Digital game-based learning of stack data structure using question prompts. International Journal of Interactive Mobile Technologies, 13(7): 90-102. https://doi.org/10.3991/ijim.v13i07.10778

[29] Srisawasdi, N., Pondee, P., \& Bunterm, T. (2018). Preparing pre-service teachers to integrate mobile technology into science laboratory learning: an evaluation of technologyintegrated pedagogy module. International Journal of Mobile Learning and Organisation, 12(1): 1-17. https://doi.org/10.1504/ijmlo.2018.10009961

[30] Fessakis, G., Karta, P., \& Kozas, K. (2018). Designing Math trails for enhanced by mobile learning realistic Mathematics education in primary education. International Journal of Engineering Pedagogy, 8(2): 49-63. https://doi.org/10.3991/ijep.v8i2.8131

[31] Cheong, J.H., \& Park, M.C. (2005). Mobile internet acceptance in Korea. Internet Research, 15(2): 125-140. https://doi.org/10.1108/10662240510590324

[32] Robinson, J.P., Shaver, P.R., \& Wrightsman, L.S. (1991). Measures of personality and social psychological attitudes. Academic Press.

[33] Chow, M., Chen, L., Yeow, L., \& Wong, P. (2012). Conceptual paper: factors affecting the demand of smartphone among young adult. International Journal on Social Science Economics \& Art, 2(2): 45-49.

\section{Authors}

Hana A.B Elammari is member of the International Higher Institute for Sciences and Technology-Al Garaboulli, AL Garaboulli Libya. Her interests are smartphone, $\mathrm{m}$-learning, and technology-based learning environment. Address for correspondence: mum.modymram@gmail.com

Nadire Cavus is a lecturer at the Department of Computer Information Systems, Near East University, Cyprus. Her interests are technology, mobile learning, virtual learning environments, and distant learning. Email: nadire.cavus@neu.edu.tr

Article submitted 2019-09-24. Resubmitted 2019-10-18. Final acceptance 2019-10-21. Final version published as submitted by the authors. 